\title{
Larval development of Calyptraeotheres garthi (Fenucci, 1975) (Brachyura, Pinnotheridae) described from laboratory-reared material, with notes of larval character use on Pinnotheridae systematic
}

\author{
Emiliano H. Ocampo • Jesús D. Nuñez • \\ Marta S. Lizarralde • Maximiliano Cledón
}

Received: 10 May 2010/Revised: 6 September 2010/ Accepted: 8 September 2010/Published online: 25 September 2010

(C) Springer-Verlag and AWI 2010

\begin{abstract}
Calyptraeotheres garthi (Brachyura, Pinnotheridae) is a pinnotherid crab that lives in association with some species of Crepidula sp. (Calyptraeidae). The larvae of $C$. garthi were cultured under laboratory conditions $\left(20^{\circ} \mathrm{C}\right.$ and $\left.35 \mathrm{PSU}\right)$. Larval development from hatchling to megalopa took 30 days. Five zoeal stages and the megalopa are described and fully illustrated. The genus Calyptraeotheres consists only of four species. Larval characters were compared with the previous description of larvae from the southeastern Pacific species $C$. politus and with Tumidotheres maculatus a closely related pinnotherid crab. In addition, in light of recent molecular phylogeny of the family Pinnotheridae, we present a discussion about the Calyptraeotheres and its close related genera.
\end{abstract}

Communicated by H.-D. Franke.

E. H. Ocampo $(\bowtie) \cdot$ J. D. Nuñez · M. Cledón EGEM-Laboratorio de Ecología y Genética de Especies Marinas, Dpto. de Cs. Marinas, FCEyN, Universidad Nacional de Mar del Plata, Funes 3350, Mar del Plata 7600, Argentina e-mail: eocampo@mdp.edu.ar

E. H. Ocampo · J. D. Nuñez · M. Cledón

Aquarium Mar del Plata, Av. Martínez de Hoz 5600,

Mar del Plata 7600, Argentina

E. H. Ocampo - J. D. Nuñez · M. S. Lizarralde · M. Cledón CONICET-Consejo Nacional de Investigaciones Científcas y Técnicas, Av. Rivadavia 1917, CP C1033AAJ,

Cdad de Buenos Aires, Argentina

M. S. Lizarralde

CREG-Centro Regional de Estudios Genómicos, Av. Calchaquí km. 23,5 (1888), Florencio Varela, Buenos Aires, Argentina
Keywords Calyptraeotheres garthi $\cdot$ Zoea $\cdot$ Megalopa Systematic $\cdot$ Pinnotheridae $\cdot$ Southwestern Atlantic

\section{Introduction}

The family Pinnotheridae is composed of approximately 304 species of small-sized crabs (De Grave et al. 2009) most of them living in association with many benthic invertebrates like mollusks, ascidians, annelids, other crustaceans, echiurans, or echinoderms (Schmitt et al. 1973). With the exception of Tunicotheres moseri (Bolaños et al. 2004), the larvae of pinnotherids are free-living and the number of zoeal stages ranges from 2 to 5 . The genus Calyptraeotheres Campos, 1990 consists of four species: Calyptraeotheres garthi Fenucci, 1975 from southwestern Atlantic, C. hernandezi Hernández-Ávila and Campos, 2006 from Cubagua Island, Venezuela, C. granti Glassell, 1933, and C. politus Smith, 1870 from the eastern and southeastern Pacific, respectively. All of these species are obligatory symbiont of slipper limpets of the molluscan family Calyptraeidae. Up to day, only the larval development of $C$. politus has been formally studied (Saelzer and Hapette 1986).

Phylogeny and classification of the pinnotherids have been the aim of many revisions based on adults and larvae morphology and DNA sequences (Ahyong and $\mathrm{Ng}$ 2007; Campos 1996a, b, 2009; Griffith 1987; Marques and Pohle 1995; Palacios-Theil et al. 2009; Pohle and Marques 1998). Particularly, the genera Calyptraeotheres and Tumidotheres have been the focus of debate. Upon larval morphological characters, Marques and Pohle (1995) suggested the species Pinnotheres politus (now Calyptraeotheres politus) should be included in the genus Tumidotheres. Then, throughout morphology of adult crabs, Campos 
(1999) transferred the pinnotherid species, which lives as obligatory symbiont of slipper limpet (family Calyptraeidae), to the genus Calyptraeotheres. Finally, the phylogeny made on the basis of mitochondrial genes shows a closer relationship between the genera Tumidotheres and Calyptraeotheres (Palacios-Theil et al. 2009).

In the present study, the larval development of Calyptraeotheres garthi from Las Grutas, Río Negro (Argentina), is described and illustrated. In addition, an exhaustive comparison is made with not only $C$. politus but also with Tumidotheres maculatus in order to discuss the systematic position of these genera. Moreover, in light of recent molecular phylogeny of the family Pinnotheridae (PalaciosTheil et al. 2009), we presented larval remarks about Calyptraeotheres and its close related genera.

\section{Materials and methods}

Individuals of the host Crepidula sp. were obtained from the commercial fleet near to Piedras Coloradas $\left(40^{\circ} 57^{\prime} \mathrm{S}\right.$, $65^{\circ} 04^{\prime} \mathrm{W}$ ), Río Negro, Argentina, on March 23, 2009. The limpets were transported to IBMP (Instituto de Biología Marina y Pesquera, Almirante Storni), and 12 of them were placed individually in aquaria with $1-\mu \mathrm{m}$ filtered seawater. In San Matías Gulf, the prevalence of $C$. garthi is around $80 \%$, so we preferred to cultivate hosts in order to avoid the stress that crabs would suffer when taken off. The larvae of four incubating females started to hatch on March 29 and were transferred to individual beakers of $25 \mathrm{ml}$ capacity. Natural seawater was used at a temperature of $20^{\circ} \mathrm{C}$ and salinity of 35 PSU. Larvae were cultured under artificial light regime: 12/12 h (L/D). The first, second, and third zoeae were fed with a mixed culture of algae Nannochlorophis oculata/Tethraselmis suecica and rotifers Brachionus plicatilis ad libitum, and the fourth and fifth zoeae were fed with a mix of rotifers and nauplii of Artemia salina. Water and food were changed every day. In addition, the Artemia salina was reared with antibiotic-treated seawater (Cloranfenicol, $50 \mu \mathrm{g} / \mathrm{ml}$ ). Several individuals of each stage were preserved in $4 \%$ formaldehyde.

Specimens were dissected under a Zeiss Axio Scope 2 stereomicroscope. Measurements and drawings were made using an Olympus SZ-SC compound microscope equipped with a camera lucida. Drawings in zoea were based on 5 larvae per stage and measurements on 10 larvae. Drawings and measurements in megalopa were based on 5 individuals. In zoea, rostrodorsal length (RDL) was measured from the rostral spine tip to the dorsal spine tip; carapace length (CL) from the base of the rostrum to the posterior margin; carapace width $(\mathrm{CW})$ as the distance between the tips of the lateral spines. In megalopa, carapace CL was measured from of rostrum to the posterior margin and the
$\mathrm{CW}$ as the maximum width of the carapace. In addition, for the first and fourth zoeae, two illustrations have been shaded in order to show the animals aspect as natural as possible.

Descriptions were arranged according to the standard proposed by Clark et al. (1998). The different kinds of setae were named sensu Bookhout and Costlow (1974, 1977) and Pohle and Telford (1981). The zoea I and megalopa were completely described here, and for the rest of zoeae, only differences with precedents stages were detailed. Samples of larvae and the adult female were deposited in the Museo Argentino de Ciencias Naturales "Bernardino Rivadavia" under the catalog number MACN-IN 37722.

\section{Results}

The larvae development of Calyptraeotheres garthi took place through five zoeal and one megalopa stages. Six zoeae from a single female reached the megalopal stage, in at least 30 days after hatching. Larvae of the three other females failed to reach the megalopa. In the Table 1 are represented the mean sizes and first day of appearance of each stage. These data were based on the larvae of the hatch, which reached the megalopa.

\section{Zoea I}

Carapace (Fig. 1a, b) Globose and smooth, without tubercles. Rostral and dorsal spines well developed. Lateral spines prominent and slightly curved downwards. One pair of simple posterodorsal setae flanking dorsal spine. Eyes sessile. Each ventroposterior margin without setae.

Antennule (Fig. 1c) Uniramous. Endopod absent. Exopod unsegmented with 2 aesthetascs (1 long, 1 shorter and thinner than the first one) and 1 seta.

Table 1 Mean $( \pm \mathrm{SD})$ rostrodorsal length (RDL), carapace width $(\mathrm{CW})$, carapace length (CL) in $\mathrm{mm}$, and first day appearance of the larval stages of Calyptraeotheres garthi reared in the laboratory

\begin{tabular}{lllll}
\hline Estadio & RDL & CW & CL & $\begin{array}{c}\text { 1st day to } \\
\text { appear }\end{array}$ \\
\hline Zoea I & $1.03 \pm 0.07$ & $0.51 \pm 0.05$ & $0.43 \pm 0.01$ & 0 \\
Zoea II & $1.33 \pm 0.05$ & $0.61 \pm 0.07$ & $0.48 \pm 0.02$ & 5 \\
Zoea III & $1.74 \pm 0.11$ & $0.71 \pm 0.10$ & $0.59 \pm 0.03$ & 10 \\
Zoea IV & $2.03 \pm 0.15$ & $0.91 \pm 0.11$ & $0.68 \pm 0.04$ & 14 \\
Zoea V & $2.24 \pm 0.25$ & $0.99 \pm 0.13$ & $0.73 \pm 0.09$ & 22 \\
Megalopa & - & $0.73 \pm 0.03$ & $0.80 \pm 0.03$ & 30 \\
\hline
\end{tabular}

All measures were taken from the larvae of the hatch that reached the megalopa 
Fig. 1 Calyptraeotheres garthi. Zoea I. a General view, b lateral view, $\mathbf{c}$ antennule, $\mathbf{d}$ antenna, e mandibles, $\mathbf{f}$ maxillule, g maxilla, $\mathbf{h}$ first maxilliped, i second maxilliped, $\mathbf{j}$ abdomen, dorsal view

Antenna (Fig. 1d) Uniramous. Protopod with spinous process armed with spines arranged in two lines. Endopod and exopod absent.

Mandible (Fig. 1e) With circular serrated molar region and one incisor processes with 2-3 flanking lateral tooth. Cuticle brown distally. Palp absent.

Maxillule (Fig. 1f) Coxal endite with 4 plumodenticulate setae. Basial endite with 5 setae, 1 simple, 1 plumodenticulate and 3 plumodenticulate cuspidate. Endopod 2-segmented, proximal segment without setae and distal segment with 4 terminal plumodenticulate setae. Exopod setae absent.
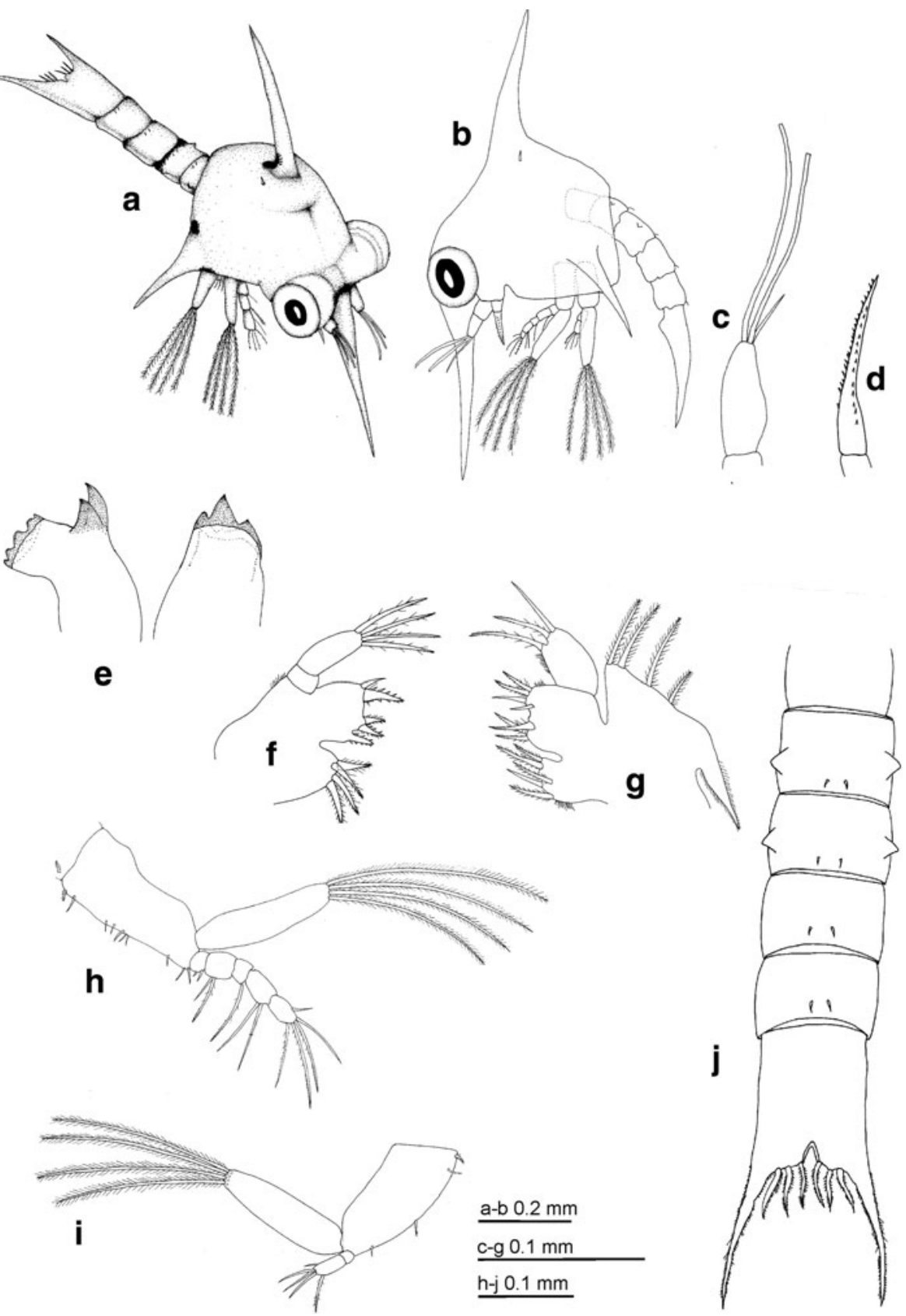

Maxilla (Fig. 1g) Coxal endite simple lobed with five setae (4 plumose and 1 simple). Basial endite weakly bilobed with 3 plumodenticulate setae +4 (2 plumodenticulate and 2 simple) setae. Endopod slightly bilobed with 3 setae, 1 of them simple and the others 2 plumodenticulate. Scaphognathite with 4 marginal densely plumose setae and a long posterior process.

First maxilliped (Fig. 1i) Coxa with 1 plumose seta. Basis with 10 setae arranged in four groups: 2 (1 plumose, 1 simple), 2 simple, 2 simple, and 3 simple. Endopod 5-segmented with 2 simple, 2 ( 1 simple, 1 plumodenticulate), 1 plumodenticulate, 2 simple, 5 (1 lateral simple, 3 
terminal plumodenticulate, and 1 terminal simple) setae. Exopod unsegmented, with 4 long terminal natatory plumose setae.

Second maxilliped (Fig. 1h) Coxa without setae. Basis with 4 setae: 2 proximal (1 simple, 1 sparcely plumose), 1 medial simple and 1 distal simple setae. Endopod 2-segmented, proximal segment without setae, distal segment with 1 subterminal plumodenticulate, 1 short subterminal simple, and 3 terminal simple setae. Exopod unsegmented with 4 long terminal natatory plumose setae.

Third maxilliped Absent.

Pereiopods Absent.
Abdomen (Fig. 1j) Five abdominal somites. Somites 2-5 with pair of posterodorsal simple setae. Somites 2-3 with pair of dorsolateral processes.

Telson (Fig. 1j) Smooth, bifurcated, and elongate. Furcal arms with small spines on lateral margins. Furcal arch with three plumodenticulate setae on either side of distinct median depression.

\section{Zoea II}

Carapace (Fig. 2a) Two pairs of simple setae on dorsolateral border of the eyes and halfway between eyes and dorsal spine. Each ventroposterior margin with 1 pair of

Fig. 2 Calyptraeotheres garthi.

Zoea II. a Lateral view, b antennule, c antenna,

d maxillule, e maxilla, f first maxilliped, $\mathbf{g}$ second maxilliped, $\mathbf{h}$ abdomen, dorsal view

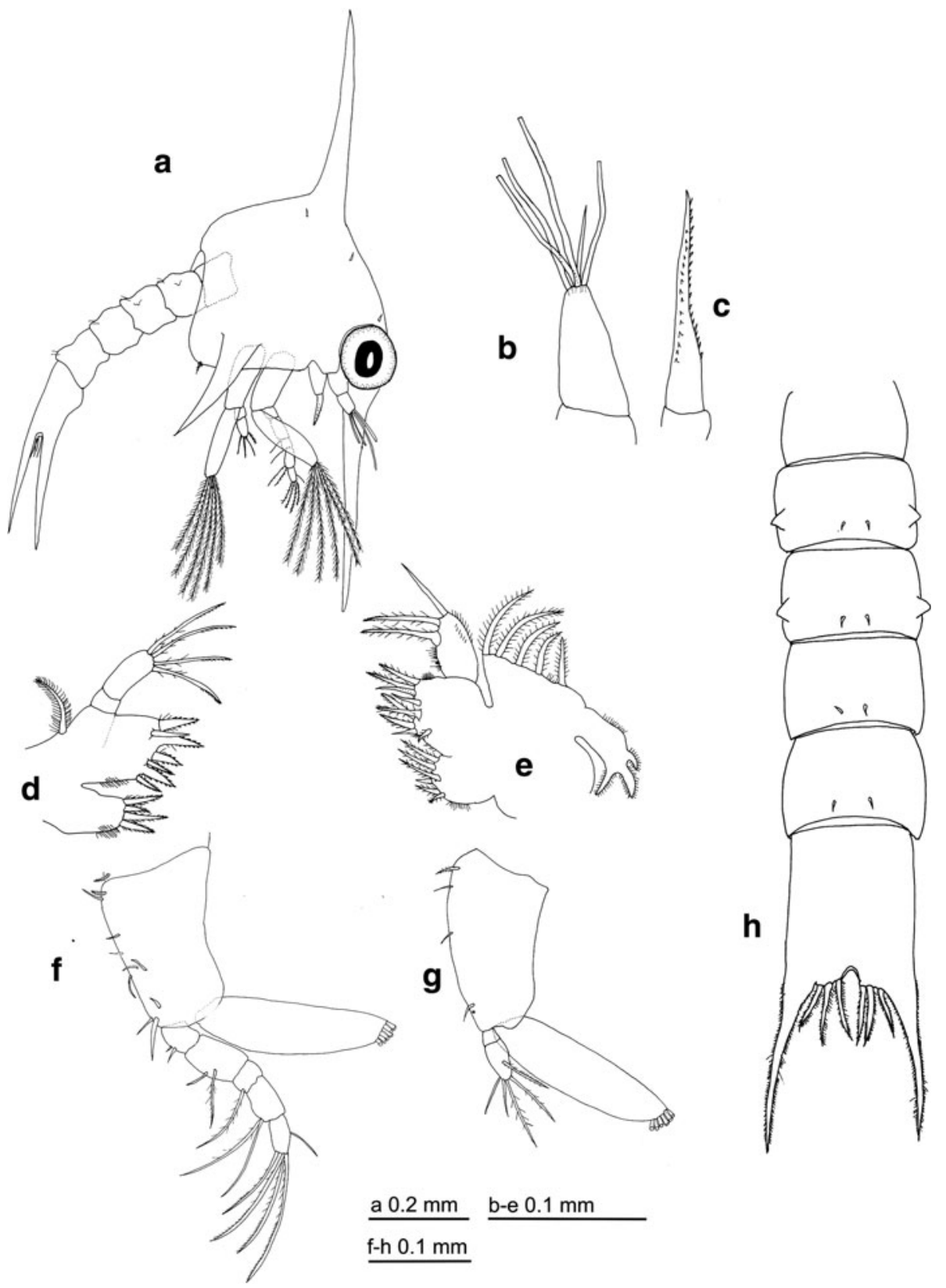


Fig. 3 Calyptraeotheres garthi.

Zoea III. a Lateral view,

b antennule, c antenna,

d maxillule, e maxilla,

f first maxilliped, $\mathbf{g}$ second maxilliped, $\mathbf{h}$ developing third maxilliped and pereiopods,

i abdomen, dorsal view

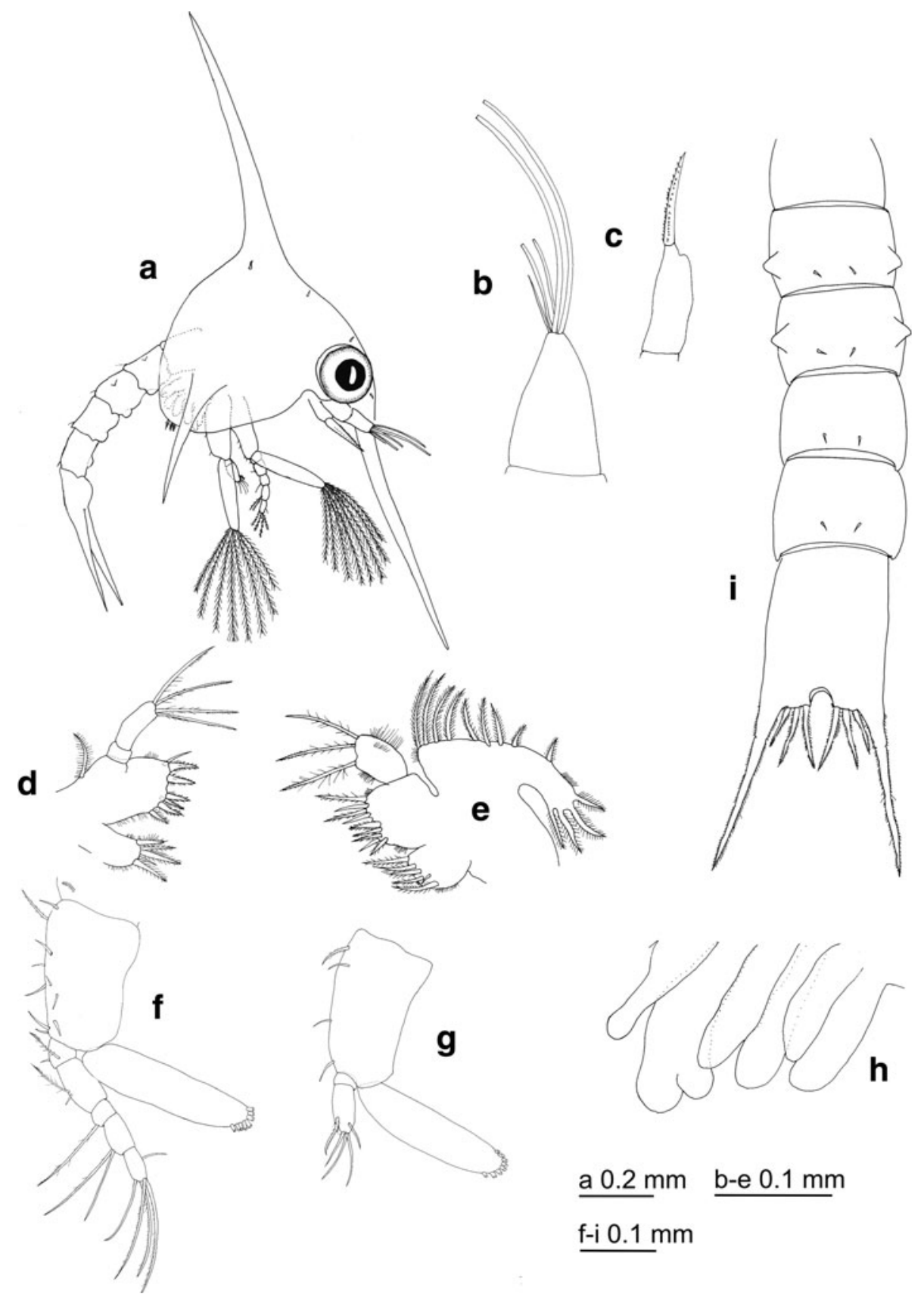

plumodenticulate setae. Eyes stalked. Antennule (Fig. 2b). Exopod now with 4 terminal aesthetascs (1 slightly longer than the others).

Maxillule (Fig. 2d) Basial endite now with 7 setae: 1 simple, 2 plumodenticulate and 4 plumodenticulate cuspidate. Exopod seta now present.

Maxilla (Fig. 2e) Coxal endite with 5 plumose and 1 short simple setae. Basial endite with 5 (4 plumodenticulate and 1 short simple) and 4 (2 plumodenticulate, 2 simple) setae. Scaphognathite bearing 8 marginal densely plumose setae.

First maxilliped (Fig. 2f) Endopod now with 2 (1 simple, 1 sparsely plumose), 5 (1 lateral simple, 4 terminal plumodenticulate) setae on the segments 4 and 5 , respectively. Exopod now with 6 long terminal natatory plumose setae.

Second maxilliped (Fig. 2g) Exopod bearing 6 long terminal natatory plumose setae. 
Third maxilliped Absent.

Pereiopods Absent.

\section{Zoea III}

Carapace (Fig. 3a) Additional pair of simple setae on the basis of rostral spine. Three plumodenticulate setae on ventroposterior margin.

Antennule (Fig. 3b) Exopod with 2 long and 2 thin and short aesthetascs.

Antenna (Fig. 3c) With rounded, undifferentiated endopodite bud reaching of the distal portion of protopodite.

Maxillule (Fig. 3d) Coxal endite with 4 plumodenticulate and 1 small simple setae.

Maxilla (Fig. 3e) Scaphognathite now with 13 marginal densely plumose setae.

First maxilliped (Fig. 3f) Endopod now bearing 1 simple and 1 plumodenticulate setae on the first segment. Exopod now with 8 long terminal natatory plumose setae.

Second maxilliped (Fig. 3g) Exopod with 8 long terminal natatory plumose setae.

Third maxilliped (Fig. 3h) Present as undifferentiated bud.

Pereiopods (Fig. 3h) Present as undifferentiated buds. Chela slightly bilobed.

Abdomen (Fig. 3i) Pleopod buds present but without endopods.

\section{Zoea IV}

Carapace (Fig. 4a, b) 6 plumodenticulate setae on ventroposterior margin.

Antennule (Fig. 4c) Biramous. Small endopod bud. Exopod with 4 aesthetascs (3 long and 1 thin and short) and 2 setae. Optionally some aesthetascs bear minute spines on the tip.

Antenna (Fig. 4d) Endopodite bud about half length of the protopodal process.

Maxillule (Fig. 4e) Coxal endite with 5 plumodenticulate setae. Basial endite with: 2 simple, 3 plumodenticulate and 4 plumodenticulate cuspidate setae. A short plumose seta is present on the lateral margin.

Maxilla (Fig. 4f) Basial endite with 5 (4 plumodenticulate, 1 simple), 5 (3 plumodenticulate, 2 simple) setae. Scaphognathite with 17 marginal densely plumose setae.
Second maxilliped (Fig. 4h) Exopod with 10 long terminal natatory plumose setae.

Third maxilliped (Fig. 4i) Biramous. Exopod and endopod present as undifferentiated buds.

Pereiopods (Fig. 4i) Longer. Chela differentiated.

Abdomen (Fig. 4j) Pleopods longer, unsegmented and uniramous.

\section{Zoea V}

Carapace (Fig. 5a, b). Additional pair of simple setae between the eyes. 7 plumodenticulate setae on ventroposterior margin.

Antennule (Fig. 5c) Biramous. Endopod bud developing. Exopod now with 6 aesthetascs, 5 terminal and 1 subterminal. 1 aesthetasc thin and short. Minute sipines on tip of aesthetascs. 3 subterminal setae.

Antenna (Fig. 5d) Endopod now as long as protopodite.

Maxillule (Fig. 5f) Basial endite now with 2 simple, 4 plumodenticulate and 4 plumodenticulate cuspidate setae. On the lateral margin, 2 small setae (1 plumose and 1 simple).

Maxilla (Fig. 5g) Coxal endite with 7 setae (6 plumose and 1 simple). Basial endite with 6 and 6 setae, 4 plumodenticulate and 2 simple in each lobe. Scaphognathite now with 19-21 marginal densely plumose setae.

First maxilliped (Fig. 5h) Coxa with 1 additional plumose setae. Exopod with 9 long terminal natatory plumose setae.

Third maxilliped (Fig. 5j) Elongated. Now epipodite bud present.

Pereiopods (Fig. 5j) Chelipeds and pereiopods slightly segmented.

Abdomen (Fig. 5k) Pleopod 2-segmented and elongated, with rudimentary endopods.

Megalopa

Carapace (Fig. 6a) Slightly longer than broad. Rostrum ventrally deflected (approximately $60^{\circ}$ ). Each lateral margin with 9 plumodenticulate setae. Disposition of simple setae as figured. Eyes stalked.

Antennule (Fig. 6b) Peduncle 3-segmented with 0, 1 and 2 simple setae, respectively. Endopod 2-segmented with 1 subterminal and 3 terminal simple setae on distal segment. Exopod 4-segmented with 0, 2, 7 and 3 (1 terminal and 2 subterminal) aesthetascs, respectively. 
Fig. 4 Calyptraeotheres garthi. Zoea IV. a Frontal view, b lateral view, c antennule, d antenna, e maxillule, f maxilla, $\mathbf{g}$ first maxilliped, h second maxilliped, i developing third maxilliped and pereiopods, $\mathbf{j}$ abdomen, dorsal view

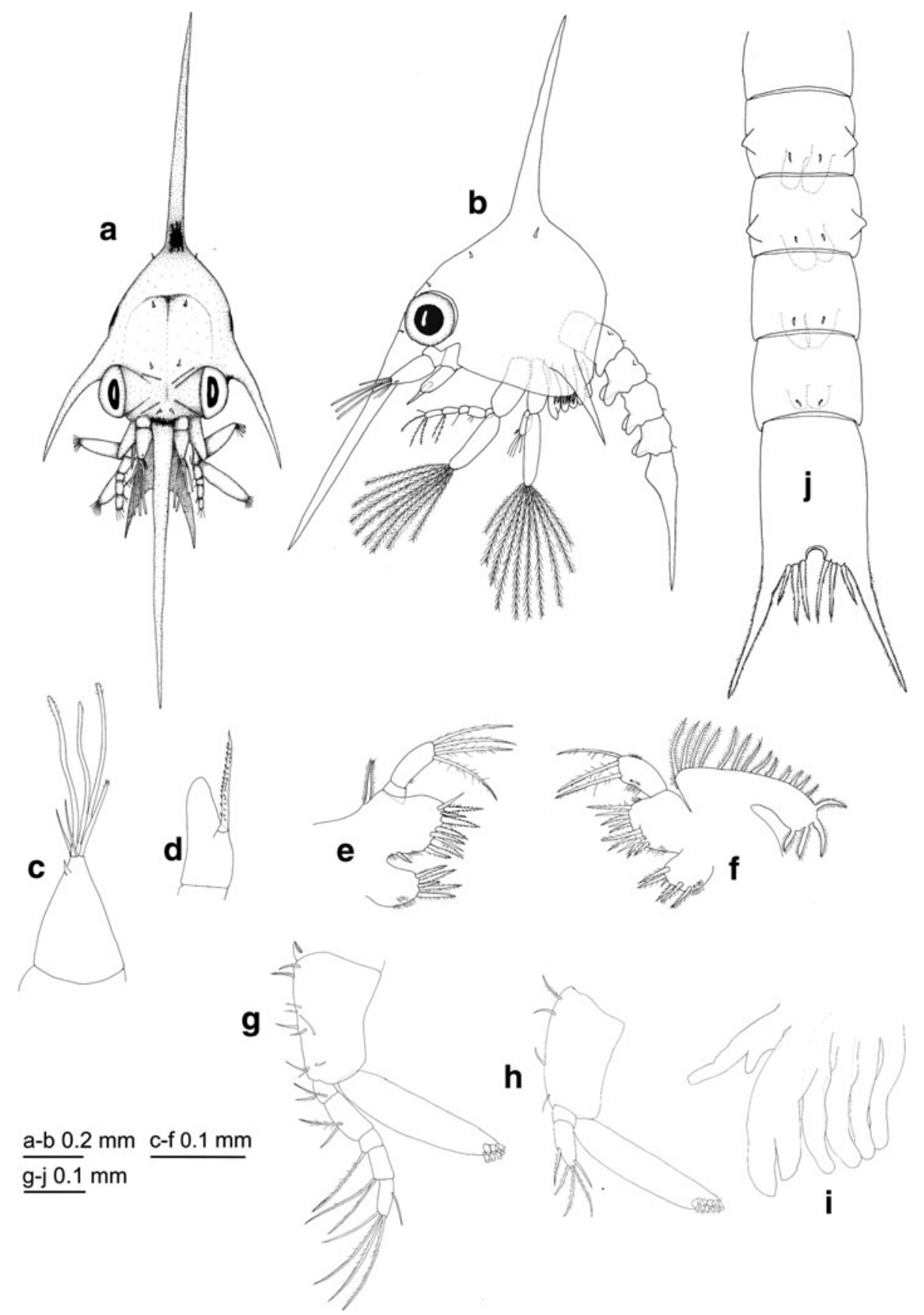

the lateral margin, 2 short plumose setae. Basally to the exopod seta, appear 1 plumodenticulate seta (may be the epipodal seta). Endopod 2-segmented without setae.

Maxilla (Fig. 6f) Coxal endite unlobed with 8 setae, 7 plumose and 1 simple. Basial endite slightly bilobed with 5 and 5 plumodenticulate setae. Endopodite reduced and without setae. Scaphognathite with 29-31 marginal densely plumose setae.

First maxilliped (Fig. 7a) Coxal endite with 1 plumose and 3 plumodenticulate setae. Basial endite with 3 plumodenticulate setae. Endopod unsegmented ending in a ticulate setae, 1 basally on lateral margin. Basial endite with: 7-8 denticulate, 8 denticulate cuspidate setae and, on 
Fig. 5 Calyptraeotheres garthi. Zoea V. a Frontal view, b lateral view, $\mathbf{c}$ antennule, $\mathbf{d}$ antenna, e mandibles, $\mathbf{f}$ maxillule, g maxilla, $\mathbf{h}$ first maxilliped, i second maxilliped,

j developing third maxilliped and pereiopods, $\mathbf{k}$ abdomen, dorsal view

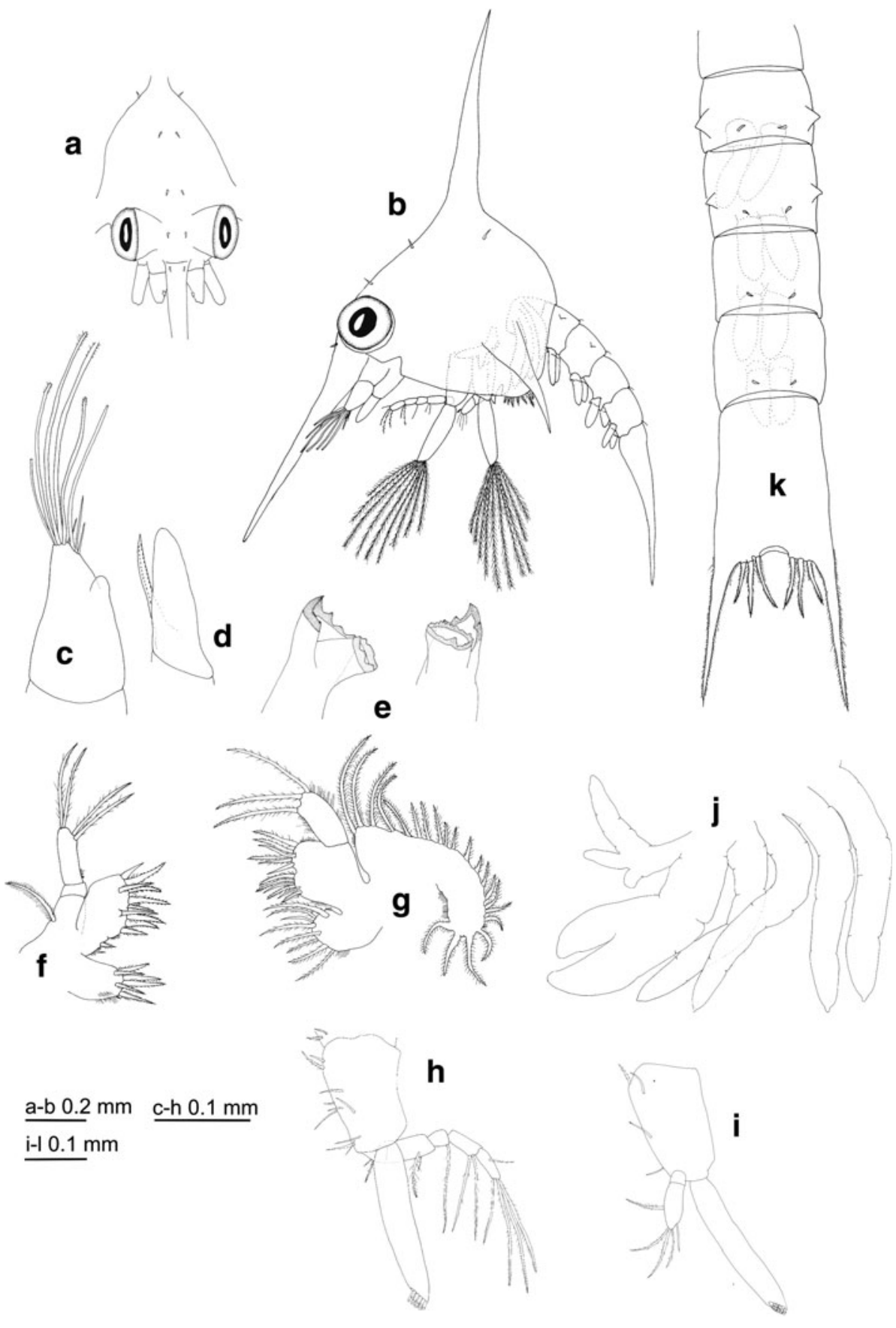

triangular shape, with 1 subterminal simple seta. Exopod 2-segmented, proximal segment with 3 plumose setae; distal segment ending in sharper shape with 3 terminal plumose setae. Epipod subtriangular with 2 medial sparsely plumose setae and 3 subterminal and 1 terminal sparsely plumose setae.

Second maxilliped (Fig. 7b) Epipodite absent. Coxa and basis not differentiated, without setae. Endopod 4-segmented, with 0, 1 long plumodenticulate, 4 plumodenticulate and 4 ( 3 plumodenticulate, 1 simple) setae, respectively.
Exopod 2-segmented with 1 medial simple and 1 distal plumose setae on proximal segment; the distal segment bear 3 long terminal simple setae.

Third maxilliped (Fig. 7c) Coxa and basis not differentiated, without setae. Endopod 4-segmented, fused ischium-merus with 2 small proximal simple, 3 medial (1 plumose and 2 simple), 2 distal (1 sparsely plumose and 1 small simple) setae; carpus with 3 (1 small simple, 1 small plumodenticulate and 1 plumodenticulate) setae; propodus with 3 plumodenticulate ( 1 subterminal) and 1 small simple 
Fig. 6 Calyptraeotheres garthi. Megalopa. a Dorsal view, b antennule, c antenna, d mandibles, e maxillule, f maxilla

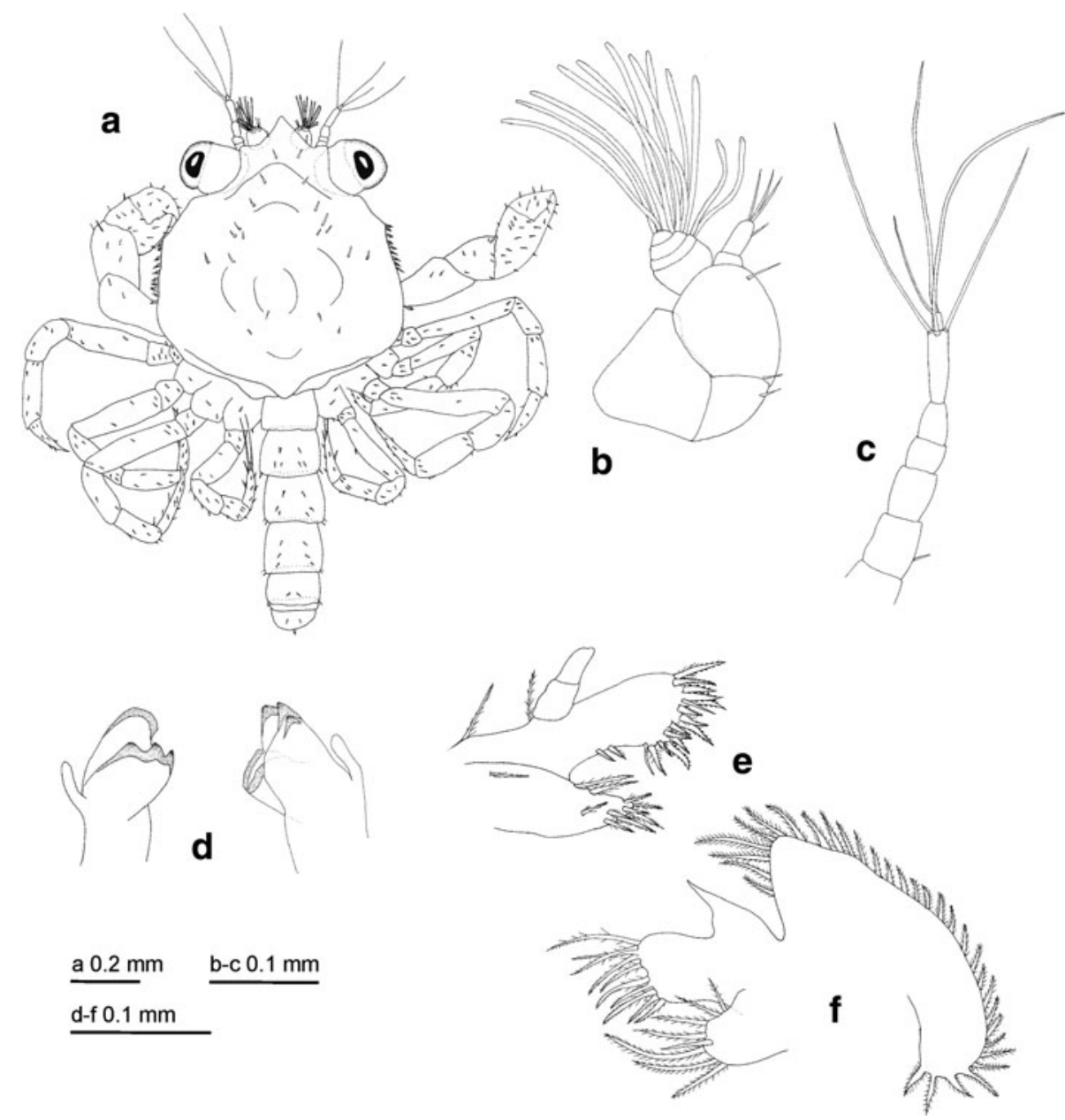

setae; dactylus with 2 plumodenticulate setae. Exopod 2 -segmented, proximal segment without setae, distal segment with 3 terminal ( 2 plumose and 1 short simple) setae. Epipod elongated with 5 medial (4 plumodenticulate and 1 short simple) and 4 terminal plumodenticulate setae.

Pereiopods (Fig. 7d, e) All segments well differentiated and with setae as figured. Dactylus of pereiopods $2-5$ with a long proximal inner spine. Dactylus of fifth pereiopod with 3 terminal simple setae (2 long and 1 shorter than these). Coxa of cheliped with 1 plumose seta.

Abdomen (Fig. 7f) Somite sixth now present, without setae. Somites bear simple setae dorsally and laterally as shown. Somites $2-5$ with a pair of biramous pleopods, each one with unsegmented and without setae endopod and 2-segmented exopod. Pleopods 1-4 bearing 8 long terminal plumose natatory setae and 1 subterminal plumose seta, pleopods on somite fifth with 6 long terminal natatory plumose setae and 1 subterminal plumose seta. Uropods absent.

Telson (Fig. 7f) Square-shaped, rounded posterior margin, with 3 dorsal setae.

\section{Discussion}

The pea crab Calyptraeotheres garthi is one of nine species of the family Pinnotheridae reported from Argentinean marine waters (Fenucci 1975; Torres 2006). Fenucci (1971) described briefly some aspects of the first zoea of this species. The observed general morphology of this stage coincides with the report by Fenucci (1971), but the carapace setae and coxal setae of the first maxilliped are described in the present work for the first time, as well as the other larval stages.

The Calyptraeotheres genus grouped four species, with only two larval developments described formally, $C$. garthi (present work) and C. politus (Saelzer and Hapette, 1986). Calyptraeotheres garthi zoeae and megalopa described here are very similar to the previously reported for C. politus (Saelzer and Hapette 1986). The larvae of both species may be distinguished only by the setation arrangement of the maxilla and the number of aesthetascs of the antennule of fifth zoea (Table 2). A third difference, the appearance of the sixth abdominal segment in the 
Fig. 7 Calyptraeotheres garthi. Megalopa. a First maxilliped, b second maxilliped, $\mathbf{c}$ third maxilliped, $\mathbf{d}$ first pereiopod, e fifth pereiopod, $\mathbf{f}$ abdomen and pleopods, lateral view
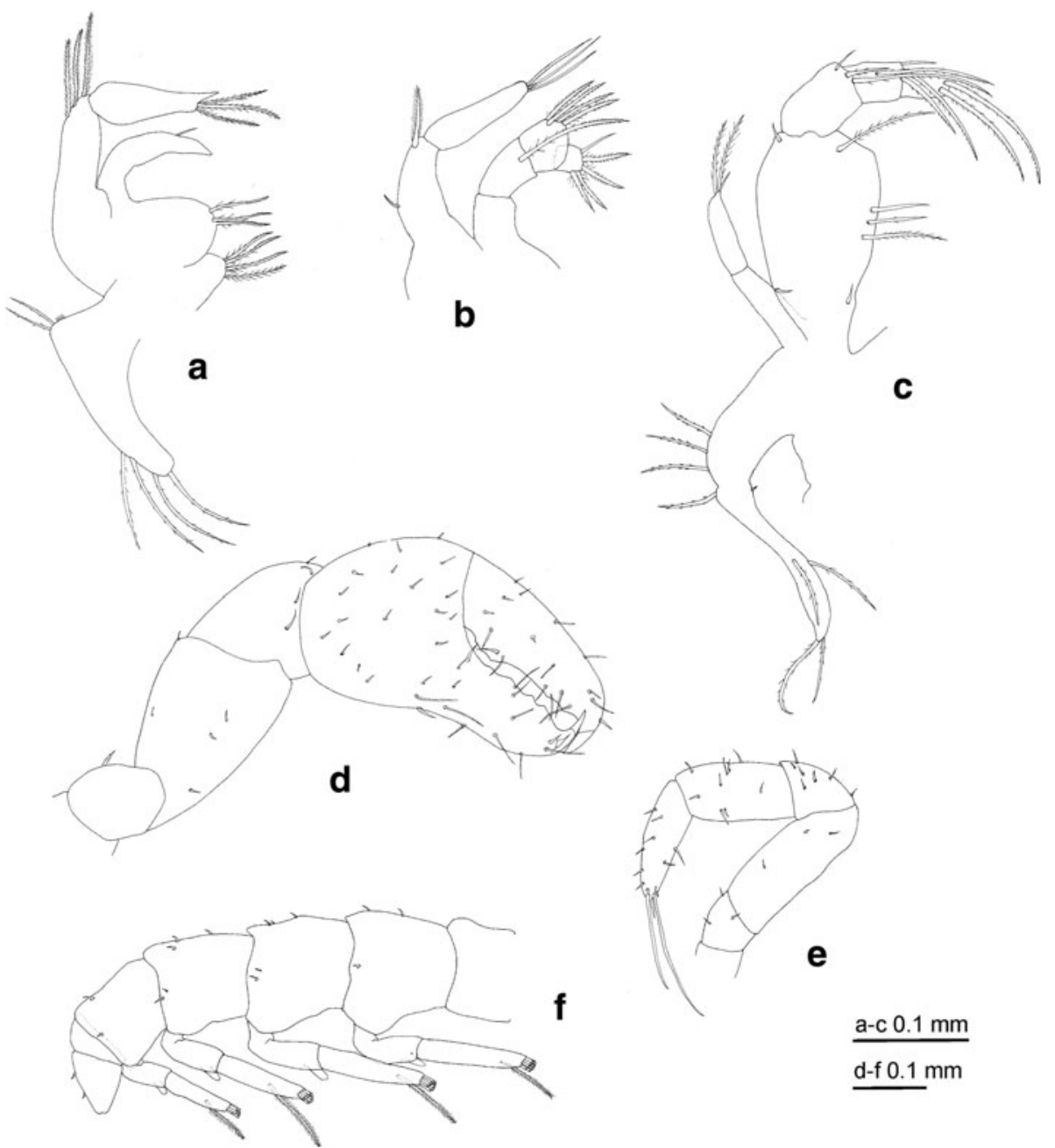

fourth zoea of $C$. politus and in the megalopa of $C$. gathi, will be discussed later.

The systematic position of the genera Calyptraeotheres and Tumidotheres has been focus of discussion (Campos 1999; Marques and Pohle 1995; Palacios-Theil et al. 2009). Due to this, an exhaustive comparison among C. garthi and reported characters of $C$. politus (Saelzer and Hapette 1986) and T. maculatus (Costlow and Bookhout 1966) was carried out here (Table 2).

The larval development of T. maculatus (Costlow and Bookhout 1966) has similarities with Calyptraeotheres. These three species have five zoeal stages in their development. Moreover, the morphology of the telson, the setation of zoeal mouthparts, and the segmentation of the megalopal antenna are almost equal. However, there are several differences, some of them referring to the time of appearance of certain characters throughout the development (Table 2). The appearance of pleopods bud and the endopod bud of antennule occurs earlier in Calyptraeotheres species than T. maculatus. In Calyptraeotheres, the marginal seta of the basial endite (maxillule) appears later than in T. maculatus.
In addition, the carapace of $T$. maculatus bears three prominent spines, character shared with other members of Pinnotheridae, but absent in Calyptraeotheres.

Two additional differences between $C$. garthi and T. maculatus, but unfortunately not described in C. politus (Saelzer and Hapette 1986), have been found. One of them is the appearance of rudimentary pereipods in the third zoea of $C$. garthi but latter in the fourth zoea in $T$. maculatus. The second character is the mandible palp, which is present in fifth zoea of T. maculatus but in the megalopa of C. garthi.

As mentioned above, in C. garthi, the sixth abdominal segment appears in the megalopa while $C$. politus and T. maculatus develop this segment in the fourth zoea. Up to now, variations in the number of the abdominal segment among congeneric species, such as those found here, were not reported in Pinnotheridae. Thus, this striking particularity of Calyptraeotheres may lead to an erroneous interpretation of the phylogeny of the genus.

In this sense, the larval phylogeny postulated by Marques and Pohle (1995) shows a group which encompasses 
Table 2 Differences among the larval morphology of Calyptraeotheres garthi, C. politus (described by Saelzer and Hapette 1986), and

Tumidotheres maculatus (described by Costlow and Bookhout 1966)

\begin{tabular}{|c|c|c|c|}
\hline & \multicolumn{2}{|c|}{ Calyptraeotheres } & \multirow{2}{*}{$\begin{array}{l}\text { Tumidotheres } \\
\text { maculatus }\end{array}$} \\
\hline & C. garthi & C. politus & \\
\hline \multicolumn{4}{|l|}{ Antennule } \\
\hline Endopod bud (appearance) & ZIV & ZIV & $\mathrm{ZV}$ \\
\hline Exopod aesthetascs + setae & $3-5-5-7-9$ & $3-5-5-7-11$ & $3-5-6-6-10$ \\
\hline Appearance of mandibular palp & Megalopa & Not described & $\mathrm{ZV}$ \\
\hline \multicolumn{4}{|l|}{ Maxillule } \\
\hline $\begin{array}{l}\text { Appearance setae on the lateral } \\
\text { margin of the basial endite }\end{array}$ & ZIV & ZIV & ZIII \\
\hline Coxal endite setae & $4-4-4-5-6$ & $4-4-4-5-6$ & $4-6-6-6-9$ \\
\hline Basial endite setae & $5-7-7-9-10$ & $5-7-7-9-10$ & $5-7-7-12-12$ \\
\hline \multicolumn{4}{|l|}{ Maxilla } \\
\hline Coxal endite setae & $5-6-6-6-7$ & $5-5-5-6-9$ & $4-6-6-7-8$ \\
\hline Basial endite setae & $7-9-9-10-12$ & $8-9-9-10-10$ & $9-9-9-11-16$ \\
\hline Scaphognathite marginal setae & $4-8-13-17-21$ & $4-8-13-19-30$ & $4-8-14-20-25$ \\
\hline \multicolumn{4}{|l|}{ First maxilliped } \\
\hline Basis setae & 10 & 9 & $3 ?$ \\
\hline \multicolumn{4}{|l|}{ Second maxilliped } \\
\hline Basis setae & 4 & 4 & $0 ?$ \\
\hline Appearance of pereiopods bud & ZIII & Not described & ZIV \\
\hline \multicolumn{4}{|l|}{ Abdomen } \\
\hline Appearance 6th segment & Megalopa & ZIV & ZIV \\
\hline Appearance pleopod buds & ZIII & ZIII & ZIV \\
\hline \multicolumn{4}{|l|}{ Megalopa } \\
\hline Carapace spines & 0 & 0 & 3 \\
\hline
\end{tabular}

P. politus (now Calyptraeotheres politus) and T. maculatus, but excludes $C$. granti. In our opinion, the hypothesis that each genus is monophyletic is strongly supported by the following facts: (1) Campos (1999) pointed out the differences between crab adult morphology of Tumidotheres and Calyptraeotheres (2) Tumidotheres and Calyptraeotheres live within bivalve species and in slipper limpets, respectively. (3) At least the known Calyptraeotheres larvae (see table 2) show differences when compared to the larvae description of Tumidotheres. Thus, the contrary results found by Marques and Pohle (1995) would be due to the fact that the authors used the number of abdominal segments in their analysis and, for this character, assigned different conditions for $C$. politus and T. maculatus than for C. granti (see methodological section of Marques and Pohle 1995). Since the segmentation of the abdomen is variable within same genus, this character should be analyzed with care in future phylogenetic studies including Calyptraeotheres.

According to the DNA phylogeny postulated by PalaciosTheil et al. (2009), the genus Tumidotheres is neighbor of Calyptraeotheres within the clade IIC, while DissodactylusClypeasterophilus and Tunicotheres (see Fig. 1 of Palacios-
Theil et al. 2009) are positioned in other branch of the same clade.

Although a formal cladistic analysis is necessary in order to demonstrate whether there is correspondence between larval morphology of these genera and the DNA phylogeny, some remarkable features were discussed here.

In the Table 3, the larval differences among some species of the clade IIC are listed. The species Pinnaxodes major, which is positioned close to Holothuriophilus within another clade (IIB) sensu Palacios-Theil et al. (2009), was also included in such comparison because this species share important features with T. maculatus.

For Tunicotheres and Dissodactylus-Clypeasterophilus, the larval morphology seems to be consistent with the molecular arrangement mentioned above, since both genera share five segments in the megalopal antenna, two dorsal spines on the zoeal telson and a seta on the first somite of the zoeal abdomen.

Simultaneously, several larval similarities between Calyptraeotheres and Tumidotheres have been found in our comparison (Tables 2, 3). However, Tumidotheres shares important characteristics with Pinnaxodes major (described by Hong 1974). Both genera, Tumidotheres and 
Table 3 Larval comparison among Calyptraeotheres (present work and Saelzer and Hapette 1986), Tumidotheres maculatus (described by Costlow and Bookhout 1966), some species of DissodactylusClypeasterophilus group [Dissodactylus mellitae, D. crinitichelis and
Clypeasterophilus stebbingi described by Marques and Pohle (1996a), Pohle and Telford (1981) and Marques and Pohle (1996b), respectively], Tunicotheres moseri (described by Bolaños et al. 2004) and Pinnaxodes major (described by Hong 1974)

\begin{tabular}{|c|c|c|c|c|c|}
\hline & Calyptraeotheres species & $\begin{array}{l}\text { Tumidotheres } \\
\text { maculatus }\end{array}$ & $\begin{array}{l}\text { Pinnaxodes } \\
\text { major }\end{array}$ & $\begin{array}{l}\text { Tunicotheres } \\
\text { moseri }\end{array}$ & $\begin{array}{l}\text { Dissodactylus- } \\
\text { Clypeasterophilus }\end{array}$ \\
\hline Zoea stages & 5 & 5 & 5 & 2 & $3-4$ \\
\hline $\begin{array}{l}\text { Antennule endopod bud } \\
\text { (appearance) }\end{array}$ & ZIV & $\mathrm{ZV}$ & $\mathrm{ZV}$ & ZI & ZIII-ZIV or not develop \\
\hline $\begin{array}{l}\text { Antenna endopodite bud } \\
\text { (appearance) }\end{array}$ & ZIII & ZIII & ZIV & ZI & ZII-ZIII \\
\hline Appearance of mandibular palp & $\begin{array}{l}\text { Megalopa but not } \\
\text { described in } \\
\text { C. politus }\end{array}$ & $\mathrm{ZV}$ & $\mathrm{ZV}$ & - & $\begin{array}{l}\text { Megalopa or not } \\
\text { develop }\end{array}$ \\
\hline \multicolumn{6}{|l|}{ Maxillule } \\
\hline $\begin{array}{l}\text { Appearance setae on the lateral } \\
\text { margin of the basial endite }\end{array}$ & ZIV & ZIII & ZIV & ZII & ZIII \\
\hline First maxilliped basis setae & $10-9$ & $3 ?$ & $7-10$ & $5-6$ & 10 \\
\hline Second maxilliped basis setae & 4 & $0 ?$ & $3-4$ & $0-1$ & 4 \\
\hline Appearance of pereiopods bud & $\begin{array}{l}\text { ZIII but not described } \\
\text { in C. politus }\end{array}$ & ZIV & Not described & ZI & ZII \\
\hline \multicolumn{6}{|l|}{ Abdomen } \\
\hline Appearance pleopod buds & ZIII & ZIV & ZIV & ZI & ZII-ZIII \\
\hline Mid-dorsal setae on first somite & Absent & Absent & Absent & Present & Present \\
\hline \multicolumn{6}{|l|}{ Telson } \\
\hline \multirow[t]{2}{*}{ Dorsal spine on furcate } & Smooth & Smooth & Smooth & $\begin{array}{l}\text { Covered with } \\
\text { spinules }\end{array}$ & Covered with spinules \\
\hline & Absent & Absent & Absent & Present & Present \\
\hline \multicolumn{6}{|l|}{ Megalopa } \\
\hline Carapace spines & 0 & 3 & 3 & 0 & 0 \\
\hline Antenna segmentation & 6 & 6 & 7 & 5 & 5 \\
\hline
\end{tabular}

Pinnaxodes, bear three carapace spines in the megalopa, a segmented mandibular palp with setae, and develop the mandibular palp in the fifth zoea (Table 3).

Thus, from the point of view of the larval morphology, if Tumidotheres is the sister clade of Calyptraeotheres or, by the contrary, is the neighbor group of Pinnaxodes remains unclear. This matter will be resolved with future full comparative taxonomic analysis.

Here, we present the description of the complete larval development of $C$. garthi. In addition, we pointed out morphological traits that will improve the understanding of phylogeny of Calyptraeotheres and its close related species. Further investigation on the larval morphology of the Pinnotheridae is crucial in order to complete the understanding of the systematic of this group.

Acknowledgments We would like to thank Dr. Enrique Morsan and colleagues of the IBMP for their hospitality, Dr. Diego Luzzatto for providing us the phytoplankton, Dr. Juan Timi and co-workers for their assistance with the use of the camera lucida, the fisherman Mr. Samuel for providing the samples of Crepidula sp., and Dr. Marcelo
Scelzo and Dr. Eduardo Spivak for their advices about larval dissection. Sincere thanks are extended to Dr. Ernesto Campos and an anonymous reviewer for their suggestions and criticism that clearly improved the manuscript. The present work was partially supported by the project EXA 453/09 of Universidad Nacional de Mar del Plata and the project PICT 2007-071398 of Agencia Nacional de Promoción Científica y Tecnológica. Additional support for Emiliano H. Ocampo was provided through a doctoral scholarship funded by CONICET-Concejo Nacional de Investigaciones Científicas y Técnicas. The present results are part of the Ph.D thesis of Emiliano H. Ocampo.

\section{References}

Ahyong S, Ng PKL (2007) The pinnotherid type material of Semper (1880), Nauck (1880) and Börger (1895) (Crustacea: Decapoda: Brachyura). Raff Bull Zool 16:191-226

Bolaños J, Cuesta JA, Hernández G, Hernández J, Felder DL (2004) Abbreviated larval development of Tunicotheres moseri (Rathbun, 1918) (Decapoda, Pinnotheridae) a rare case of parental care among brachyuran crabs. Sci Mar 68:373-384

Bookhout CG, Costlow JD (1974) Larval development of Porfunus spinicarpus reared in the laboratory. Bull Mar Sci 24:20-51 
Bookhout CG, Costlow JD (1977) Larval development of Callinectes similis reared in the laboratory. Bull Mar Sci 27:704-728

Campos E (1990) Calyptraeotheres a new genus of Pinnotheridae for the limped crab Fabia granti Glassell, 1933 (Crustacea, Brachyura). Proc Biol Soc Wash 103:364-371

Campos E (1996a) Partial revision of the genus Fabia Dana, 1851 (Crustacea: Brachyura: Pinnotheridae). J Nat Hist 30:1157-1178

Campos E (1996b) Partial revision of pinnotherid crab genera with a two-segmented palp on the third maxilliped (Decapoda: Brachyura). J Crust Biol 16:556-563

Campos E (1999) Inclusion of the austral species Pinnotheres politus (Smith, 1869) and Pinnotheres garthi Fennuci, 1975 within the genus Calyptraeotheres Campos, 1990 (Crustacea: Brachyura: Pinnotheridae). Proc Biol Soc Wash 112:536-540

Campos E (2009) A new species and two new genera of pinnotherid crabs from the northeastern Pacific Ocean, with a reappraisal of the subfamily Pinnotherinae de Haan, 1833 (Crustacea: Brachyura: Pinnotheridae). Zootaxa 2022:29-44

Clark PF, Calasanz DK, Pohle GW (1998) Accuracy and standardization of brachyuran larval descriptions. Invertebr Reprod Dev 33:127-144

Costlow JD, Bookhout CG (1966) Larval stages of the crab, Pinnotheres maculatus, under laboratory conditions. Chesapeake Sci 7(3):157-163

De Grave S, Pentcheff ND, Ahyong ST et al (2009) A classification of living and fossil genera of decapod crustaceans. Raffles Bull Zoo 21:1-109

Fenucci JL (1971) Notas sobre las dos especies de Pinnotheres más comunes en el litoral bonaerense (Decapoda, Brachyura, Pinnotheridae). Physis (Buenos Aires) secc A 30:355-367

Fenucci JL (1975) Los cangrejos de la familia Pinnotheridae del litoral argentino (Crustacea, Decapoda, Brachyura). Phycis (Buenos Aires) secc A 34:165-184

Glassell SA (1933) Description of five new species of Brachyura collected on the west coast of México. Trans San Diego Soc Nat Hist 7:331-334

Griffith H (1987) Taxonomy of the genus Dissodactylus (Crustacea: Brachyura: Pinnotheridae) with descriptions of three new species. Bull Mar Sci 40:397-422

Hernández-Ávila I, Campos E (2006) Calyptraeotheres hernandezi (Crustacea: Brachyura: Pinnotheridae), a new crab symbiotic of the West Indian cup-and-saucer Crucibulum auricula (Gmelin) (Mollusca: Gastropoda: Calyptraeidae) of Cubagua Island, Venezuela. Proc Biol Soc Wash 119:43-48

Hong SY (1974) The larval development of Pinnaxodes major Ortman (Decapoda, Brachyura, Pinnotheridae) under the laboratory conditions. Publ Mar Lab Busan Fish Coll 7:87-99

Marques F, Pohle G (1995) Phylogenetic analysis of the Pinnotheridae (Crustacea, Brachyura) based on the larval morphology, with emphasis on the Dissodactylus species complex. Zool Scripta 24:347-364

Marques F, Pohle G (1996a) Laboratory-reared larval stages of Dissodactylus mellitae (Decapoda: Brachyura: Pinnotheridae) and developmental patterns within the Dissodactylus species complex. Can J Zool 74:47-72

Marques F, Pohle G (1996b) Complete larval development of Clypeasterophilus stebbing (Decapoda: Brachyura: Pinnotheridae) and a comparison with others species within the Dissodactylus complex. Bull Mar Sci 58:165-185

Palacios-Theil E, Cuesta J, Campos E, Félder D (2009) Molecular genetic re-examination of subfamilies and Polyphyly in the Family Pinnotheridae (Crustacea: Decapoda). In: Martin J, Crandall K, Felder D (eds) Decapod Crustacean phylogenetics. CRC Press, Boca Raton, pp 447-472

Pohle G, Marques F (1998) Phylogeny of the Pinnotheridae: larval and adult evidence, with emphasis on the evolution of gills. Invertebr Reprod Dev 33:229-239

Pohle G, Telford M (1981) Morphology and classification of decapod crustacean larval setae: scanning electron microscope study of Dissodactylus crinitichelis Moreira, 1901 (Brachyura, Pinnotheridae). Bull Mar Sci 31:736-752

Saelzer HE, Hapette A (1986) Desarrollo larvario de Pinnotheres politus (Smith, 1870) (Brachyura, Pinnotheridae) en condiciones de laboratorio. Gayana Zool 50:63-79

Schmitt WL, McCain JC, Davidson ES (1973) Decapoda I, Brachyura I, family Pinnotheridae. In: Gruner HE, Holthuis LB (eds) Crustaceorum Catalogus. Dr. W. Junk BV, Den Haag

Smith SI (1870) Pinnotheres margarita Smith, sp. Nov. Trans. Conn Acad Arts Sci 2:169-170

Torres ER (2006) Primer registro para Argentina de Pinnixa valdiviensis Rathbun, 1907 (Decapoda, Pinnotheridae). Invest Mar Valparaíso 34(2):175-179 